\title{
Review of the Usability of Cyclodextrin as a Cosmetic Ingredient
}

Jaeeun Lee ${ }^{1}$, Seyeon Park ${ }^{2 *}$

${ }^{1}$ Department of Health and Cosmetics, Dongduk Women's University, Seoul, Korea

${ }^{2}$ Department of Applied Chemistry, Dongduk Women's University, Seoul, Korea

\author{
"Corresponding author: Seyeon Park, \\ Department of Applied Chemistry, Dongduk \\ Women's University, 60 Hwarang-ro, 13-gil, \\ Seongbuk-gu, Seoul 02748, Korea \\ Tel.: +82 29404514 \\ Fax: +82 29404510 \\ Email: sypark21@dongduk.ac.kr
}

Received August 27, 2019

Revised November 26, 2019

Accepted November 29, 2019

Published December 30, 2019

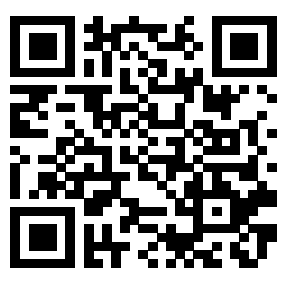

\begin{abstract}
Skin is the outermost barrier of the body, making it vulnerable to various external stimuli that can directly influence skin aging. To maximize the impact of cosmetics that delay skin aging, the stabilization of cosmetic ingredients is necessary. In addition to microencapsulation, liposome, and liquid crystal methods to increase the bioavailability of cyclodextrin, various studies have been conducted that utilize its structural characteristics to improve its properties of solubility, stability, and sustained release. In the present study, we reviewed previous investigations demonstrating that cyclodextrin enhanced the usefulness of various active ingredients as cosmetics materials based on its structural characteristics. Cyclodextrin inclusion complexes of esculin, hydrogel, coenzyme Q10, and genistein were compared with each non-inclusion material. The results showed that cyclodextrin increased solubility and improved skin permeability. Additionally, cysteinyl $\beta$-cyclodextrin, formed by combining a structural unit of the amino acid cysteine with $\beta$-cyclodextrin, showed a complexing function specific to the flavonoid baicalein. The strongly hydrophilic cysteine site of the complex improved the dissolution of baicalein in water. Therefore, further studies should investigate the various structure-specific host complexes with different cyclodextrin structure derivatives besides the cysteinyl group to enhance the already verified efficacy of the effective ingredients. Furthermore, it is expected that cyclodextrin will be commercialized as a stabilizing material for active ingredients in the cosmetic industry if clinical studies can prove the effectiveness of the $\beta$-cyclodextrin inclusion function in functional cosmetics.
\end{abstract}

Keywords: Cosmetics effective ingredient, Cosmetic ingredient stabilization technology, Cyclodextrin inclusions, Solubility, Stability

\section{Introduction}

의·과학의 발달과 경제수준의 향상으로 건강증진 및 건 강수명 연장에 대한 기대감이 지속적으로 증가하면서 건강 한 삶을 위한 많은 관심과 노력들이 증가하고 있다. 노화 지연 방법의 하나로 항노화, 항산화 성분을 이용한 건강식 품 및 화장품에 대한 연구가 계속되고 있다. 2009년 지식경 제부(現 산업통상자원부)에서 수행한 "항노화산업 육성 방안" 연구에서는 항노화 산업을 '노화-노인성질환을 예방, 치료 개선을 목적으로 의약품, 식품, 화장품, 의료기기, 건강프로그램이 연관 된 바이오기술 등을 개발하고 만들어내는 첨단바이오기술이 접목
된 새로운 신기술산업'으로 정의하고 인체의 노화 예방 및 개선, 세포와 조직의 재생기술, 피부노화 방지기술, 면역노화 방지기술 등 의약품, 의료기기, 식품, 화장품으로 범위를 제시하였다. 이에 피부노화를 지연시키기 위한 새로운 보습제의 개발과 천연물을 이용한 피부의 신진대사를 증가시키는 물질에 관한 관심이 증가 하여 그 연구가 계속되고 있다.

화장품 소재 자체로는 효능이 우수하지만 안정성, 용해성 등 이 나빠서 제형화의 어려움이 있거나 가능하더라도 피부에 흡수 가 잘 되지 않아 기대한 효능을 나타내지 못하는 경우가 흔히 있 다. 이러한 문제를 극복하기 위해서는 효능 성분의 안정성, 경 피 흡수성을 높일 수 있는 제형 기술의 확보가 필요하다(Kyong, 


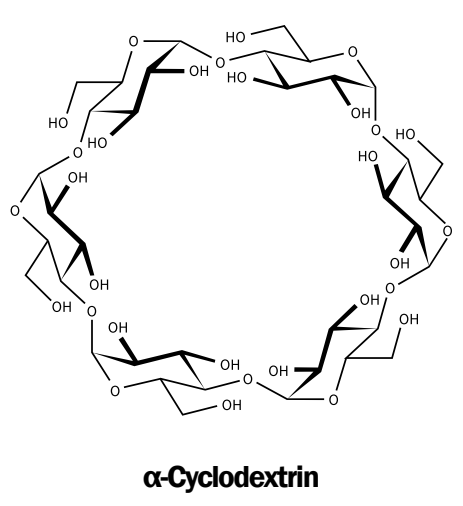

Figure 1. Structure comparison of cyclodextrin.

2010).

이에 화장품 원료의 인체에 대한 안전성을 입증하고, 유효성분 으로서의 안정성을 높여 피부에 전달력을 높이기 위한 화장품 성 분 안정화 기술에 대한 노력이 진행 중이다. 본 연구에서는 사이 클로덱스트린의 구조적 특성을 이용하여 다양한 유효성분의 화장 품 원료로서의 유용성을 높일 수 있는 선행 연구 결과를 고찰하 여 효과를 비교·검토해보고자 하였다.

\section{1. 화장품 성분 안정화 기술 방법의 발전}

피부 각질층의 낮은 투과도를 극복하기 위한 여러 안정화 기 술 방법 중 마이크로캡슐(microcapsule)화는 기능성 활성 물질 을 담지한 고체, 액체, 기체를 고분자 피막으로 코팅하여 유효성 분을 보호하고 피부를 통한 전달방법 중의 하나이다. 화장품산업 에 많이 사용되고 있으나 microcapsule화 할 때 용매로 사용되 는 오일과 폴리머 모두에 용해성이 있어야 하고, 물에도 부분적 으로 용해성이 있어야 한다(Cho, 2011). 리포좀(liposome)은 친 수성의 코어에 양친매성의 인지질과 콜레스테롤의 이중막으로 둘 러싸인 작은 인공 구형의 구조체로서 친유성과 친수성을 모두 띠 고(Jang et al., 2014) 크기와 생체 적합성 등의 이유로 널리 사 용되고 있으나, 리포좀이 가진 장점과 잠재력에 비해 리포좀의 안정성 및 유효성분의 전달 효과가 비교적 떨어진다(Drummond et al., 1999). 액정공법(liquid crystal)은 구조체 속에 유효물질 을 위치시켜 안정화를 높여 피부에 전달이 가능하여 다양한 유효 성분의 경피 흡수 증대가 기대된다(Müller-Goymann, 2004).

유효성분의 사용범위를 넓히기 위해 지난 수년간 cyclodextrin (CD) 포접 제형화를 통한 물질의 용해성 및 안정성 증진, 서방형 (徐放型)성질을 향상시켜 생체 이용률을 증가시키는 연구가 활발 히 진행되고 있다(Challa et al., 2005; Kfoury et al., 2014).

\section{Cyclodextrin의 정의 및 구조}

$\mathrm{CD}$ 는 전분을 $\mathrm{CD}$ 합성요소에 작용하는 효소(cycloamylose glucanotransferase, CGT-Ase)로 분해하여 얻은 말토올리고 당(cyclic oligosaccharides)으로 glucopyranose분자가 $\alpha-1,4-$ Glycoside 결합을 한 친수성 외부표면과 친유성 중앙의 공동(空 洞)을 갖는 환상(環狀)구조의 도넛모양을 한 구조물이다. Glucose 분자가 6 개로 결합된 $\alpha-\mathrm{CD}, 7$ 개인 $\beta-\mathrm{CD}, 8$ 개인 $\mathrm{\gamma}-\mathrm{CD}$ 로 현재 공업적으로 생산되고 있는데, 그 중에서도 $\beta-\mathrm{CD}$ 는 구조적으로 안정성이 높고 가격도 저렴하여 제약, 식품 및 화장품 산업에 다 양하게 응용되고 있다(Singh et al., 2002; Del Valle, 2004). CD 의 구조는 다음 아래 Figure 1과 같다.

$\mathrm{CD}$ 의 소수성 내부로 분자의 크기 및 성질에 따라 유입되는 guest분자는 $\mathrm{CD}$ 분자에 의해 포접되어 외부적인 요인으로부터 보 호받을 수 있을 뿐 아니라 산소, 열, 빛에 대한 안정성이 강화된다 (Del Valle, 2004). CD의 포접구조를 아래의 Figure 2에서 볼 수 있다.

특히 물에 녹지 않는 essential oil 성분과 같은 소수성 분자가 $\mathrm{CD}$ 와 복합체를 이룸으로써 용해도가 증가되어 다양한 활성이 증 가된 것으로 보고되고 있다(Kim et al., 2015). CD는 구성단위 가 glucose이므로 독성이 없고 인체에 매우 안전한 물질로서 화 장품 원료를 수용성 제형으로 녹이는데 가장 큰 강점을 가지고 있 다. 이러한 $\mathrm{CD}$ 환상의 구조물은 외부는 친수성(hydrophilic)을 나 타내고, 내부는 $\mathrm{C}-\mathrm{H}$ 와 글루코시드 산소만이 존재하여 소수성 (hydrophobic)을 나타낸다. 이러한 $\mathrm{CD}$ 의 구조적 특성은 소수성 의 공동 내에 불안정한 구조를 갖고 있는 각종 소수성 화합물인 Guest물질을 포접시켜 포접복합체를 형성할 수 있다(Figure 3).

\section{3. $\mathrm{CD}$ 의 화장품 원료로서의 유용성}

1) CD Host-Guest 포접 복합체로 인한 화장품 안정성 효과 


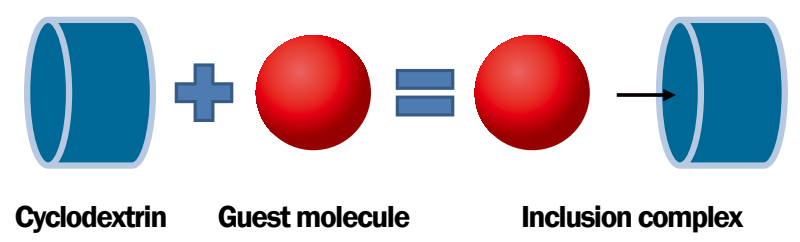

Figure 2. Cyclodextrin inclusion complex.

Guest molecules form a inclusion structure in the cyclodextrin.

Host-Guest 상호작용(interaction)을 이용하여 소수성 화합물을 공동에 포접하여 다양한 약물 전달체로 응용하는 연구가 활발하게 이루어지고 있다(Lee et al., 2012).

\section{(1) Esculin}

Esculin, 6,7-dihydroxycoumarin-2-one 6-BD-glucoside는 국화과의 약쑥(Artemisia princeps var) 같은 식물에서 발 견되는 쿠마린(coumarin) 유도체로 오랫동안 염증 및 피부 문제 를 치료하는 데 사용되어 왔다. Esculin은 쥐의 간에서 지질 과 산화 반응과 하이드록시라디칼(hydroxyl radical)을 억제하고 항 염증 활성을 보였다. Esculin은 다양한 기능성 화장품 효과를 가 지고 있으나, 물에 대한 용해도가 낮기 때문에 제한적으로 사용 되며, 빛과 산소에 의해 분해되어 생물학적 활성을 잃을 수 있다 (Kaneko et al., 2007).

Choi \& Ha (2016)의 연구에서는 esculin의 용해도를 향상시키 기 위해 hydroxypropyl $-\beta-\mathrm{CD}(\mathrm{HPCD})$ 와의 Host-Guest 포접 복합체를 제조하여 실험하였다. hydroxypropyl 기능기는 수산화 반응으로 작용기끼리 수소결합을 하고, 물과도 수소결합을 통해 친화성을 띠므로 물에 녹기 쉬운 특성을 지녀서 $\mathrm{HPCD}$ 와 형성된 복합체는 수용성이 급격히 향상된다. $\mathrm{HPCD}$ 는 $\beta-\mathrm{CD}$ 와 비교하여 서도 물에 대한 더 높은 용해도를 보이면서 메탄올, 에탄올, 디메 틸 포름 아미드, 디메틸 설폭시드와 같은 용매에도 용해 될 수 있 어 guest의 다양한 물리 화학적 특성을 향상시킬 수 있었다. 또한 실험결과에서 esculin이 함유된 에센스의 색은 6 개월 후에 변화되 었으나, esculin-HPCD 포접 복합체는 색이 변하지 않았다. 이것 은 esculin-HPCD 포접 복합체의 경우 $\mathrm{HPCD}$ 의 공동구조의 차폐 효과가 매우 안정한 화학 결합으로 연결된다는 사실로 설명 될 수 있는 것으로, esculin-HPCD 포접 복합체는 스킨케어 제품의 저 장 수명을 크게 향상시킬 수 있음을 시사하였다.

\section{(2) Hydrogel}

Hydrogel이란 수화젤이라고도 하며 수용성 고분자가 물리적 혹은 화학적 결합에 의해 3 차원의 가교를 형성하고 있는 망상구 조로서, 수용액상에서 용해되지 않고 쉽게 팽윤되는 성질을 가지 고 있다(Song et al., 2010). 또한 외부의 힘이나 물리적 자극에 의해 쉽게 부스러지고 높은 함수율(Water content)과 다공성으로

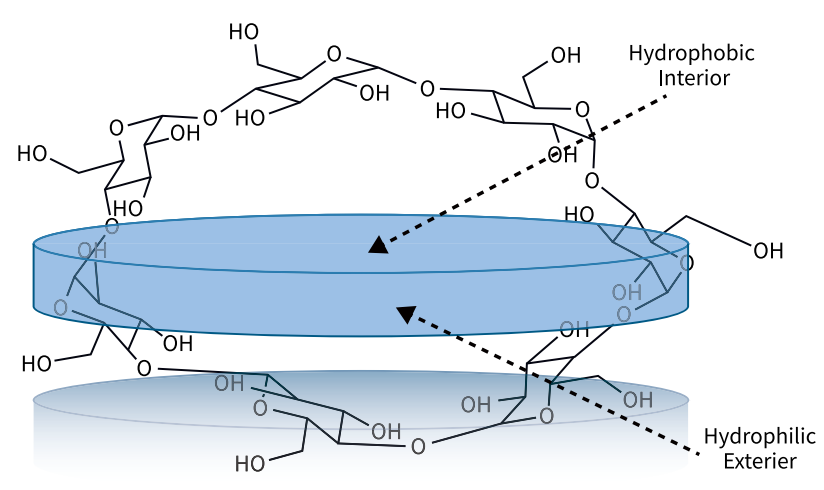

Figure 3. Structure of $\beta$-cyclodextrin.

소수성 약물성분의 탑재가 어려워 빠르게 방출하는 단점을 가지고 있다. 하지만 높은 함수율과 세포외기질(extracellular matrix)과 의 물리화학적 유사성으로 인하여 높은 생체 적합성을 갖는다.

이러한 한계점을 극복하기 위하여 Lee et al. (2012)의 연구 에서는 $\mathrm{CD}$ 를 Hydrogel에 도입함으로써 높은 함수율을 지니는 Hydrogel의 성질을 유지하면서 Host-Guest Interaction을 통하 여 소수성 약물을 효과적으로 포접하고 약물의 서방출을 가능하게 하였다. Hydrogel은 다른 약물 전달체에 비해 비교적 약물 방출 시간이 짧아 $\mathrm{CD}$ 를 도입하여 약물과 Hydrogel사이의 상호작용을 향상시킬 수 있었다.

\section{(3) Coenzyme Q10}

Coenzyme Q10 (2,3-dimethoxy-5-methyl-6decaprenyl-1,4-benzoquinone)은 식품의약품 안전청에서 인 증한 항산화 기능성 물질로 비타민C와 함께 항산화력이 강한 대 표적인 성분이다. 하지만 coenzyme Q10은 열에 안정하지 못 하여 효능을 잃어버릴 수 있다. 이러한 열 안정성을 개선하고자 Microcapsule 공법 등의 방법을 통해 coenzyme Q10의 열에 의 한 파괴를 최소화하여 효율적으로 응용할 수 있을 것으로 예상된 다. 또한 coenzyme Q10은 물에 녹지 않는 물질로 구조적 특성상 소수성기가 대부분 차지하여 용해도가 낮은 문제점을 가지고 있 다. Coenzyme Q10의 수용화 및 안정성개선과 생체 이용률을 높 이는 방법으로 $\mathrm{CD}$ 복합체를 형성하는 방법이 이미 선행연구로 진 행되었다. Lee et al. (2014)의 연구에서 Coenzyme Q10을 CD, starch를 이용하여 각각 복합체를 형성함으로써 생체이용률의 향 상을 기대할 수 있었다.

\section{(4) Genistein}

폴리페놀(polyphenol)중 하나인 이소플라본(Isoflavone)은 식 물성 피토에스트로겐(phytoestrogen)이라 불린다. 이것은 대표 적인 여성호르몬인 에스트로겐(estrogen)과 구조적으로 매우 유 사한 특징을 가지고 있어, 체내 Estrogen의 생물학적 기능과 유 
사한 기능을 나타낸다. 이 중 가장 대표적인 isoflavone이 제니 스테인(genistein, 4',5,7-trihydr oxyisoflavone)과 다이드제인 (daidzein, 4’ ,7-dihydroxyisoflavone)이다(Barne, 2010).

Genistein은 대두에서 추출한 대표적인 isoflavone 화합물 중 하나이며 노화 방지 및 항염증 활성 효과에 대한 연구가 많이 이 루어졌다. Genistein은 dimethylsulfoxide (DMSO), 에탄올 등 과 같은 유기용매에서 높은 용해도가 나타나는 반면 물에 대한 용 해성은 매우 낮아 생체이용률이 현저히 떨어지는 단점이 있다. 최근 이를 극복하기 위한 다양한 제형 연구가 수행되었다. 특히 hydroxypropyl- $\beta-\mathrm{CD}$ 포접체는 천연 화합물의 용해도, 안정성, 방출 및 생체 이용률을 향상시키기 위한 캡슐 제형으로서 널리 사 용되었다(Kfoury et al., 2014).

Choi et al. (2018)의 연구에서는 genistein의 수용성과 안정 성이 크게 향상된 genistein-CD 포접체를 직접 비교•분석하였 다. 사용된 genistein-CD 포접체는 7개의 glucopyranose ( $\alpha-$ $1,4)$ 가 결합 된 hydroxypropyl- $\beta-\mathrm{CD}$ 로 genistein과 같은 기능 성 분자들에 대한 담체 역할을 수행할 수 있어 genistein 자체가 지닌 안정성과 수용성을 크게 향상시킨 것으로 알려졌다(Tang et al., 2011). 이 연구에서 genistein과 genistein-CD 포접체를 대 상으로 항염증 및 피부장벽 강화, 세포이동 촉진 등의 효과를 비 교 관찰하여 효과적인 아토피피부염의 개선 화장품 소재 활용성을 확인하고자 하였다. 기존의 선행연구가 되어있는 genistein보다 genistein-CD 포접체는 보다 효과적으로 $\mathrm{NO}$ 생성량을 감소시키 고, 염증성 사이토카인의 유전자 발현을 억제하며 세포 이동 촉진 및 피부장벽 강화효과를 보여주었다.

따라서 genistein-CD 포접체는 genistein보다 안정성 및 피 부 투과율이 개선되었을 뿐 아니라 피부 항염증 및 피부장벽강화 또한 우위에 있는 만큼 더욱 효과적인 아토피 피부염 등의 피부질 환 개선 소재로서의 가능성을 확인하였다. 추후 염증신호 전달 기 전과 피부장벽강화 기작에 대한 추가 연구 및 피부 임상평가가 충 분히 진행된다면 아토피 피부염 환자들에게 적용할 수 있는 기능 성화장품 원료로도 개발될 수 있을 것으로 예상된다고 하였다. Cyclodextrin host-guest 포접 복합체로 인한 효과는 다음 Table 1 과 같다.
2) Methyl- $\beta-C D(M B C D)$ 의 피부 콜라겐 증진효과

Caveolin-1 (Cav-1)은 Caveolin-1 $\alpha, 1 \beta(21-24 \mathrm{kDa})$ 및 -2 (20 kDa) 단백질을 포함하는 caveolae의 주요 막단백질로, 세 포 노화를 촉진하는 핵심 분자 중 하나로서 $\mathrm{Cav}-1$ 은 노화된 피부 섬유아세포에서 증가하였고, 이것의 과다발현은 조기 세포노화를 유도하는 것으로 알려져 있다(Volonte et al., 2002).

Lee et al. (2015)의 연구에서 Cav-1과 노화피부와의 관계를 밝히고 anti-Cav-1 collagen-modulating agent의 새로운 역할 을 평가하고, $\mathrm{MBCD}$ 을 $\mathrm{Cav}-1$ 억제제로 사용하였다. 또한 쥐에서 2 개월에 2 회 피하로 투여 된 $2.5 \% \mathrm{MBCD}$ 는 피부 섬유화와 같은 부작용 없이 피부의 정상 두께 $(p<0.05)$ 를 유도하는 강력한 콜라겐 단백질 조절 활성을 나타냈다. 피부가 노화되면 피부의 총 부피감 소가 일어나고 점차 두께가 얇아지며, 연령에 따른 피부의 부피 변화는 주로 진피의 콜라겐 수치에 의해 결정된다.

따라서 노화 방지 기술은 진피의 콜라겐 발현을 증가시켜 피 부의 총 부피를 증가시키는 데 중점을 두기도 한다. 위 연구에서 $\mathrm{MBCD}$ 는 인간 진피 섬유아세포 또는 실험쥐 피부에서 콜라겐 단 백질 (COL I )발현 수준을 상향 조절함으로써 새로운 노화방지제 로 개발 될 잠재력이 있음을 증명하였다. 또한 $\mathrm{MBCD}$ 는 피부 내 로 주사했을 때, 피부와 전신 기관에 부작용을 나타나지 않아 비 교적 안전한 물질로 확인되었다. 유전적 독성 테스트에서도 유전 적 독성 반응이나 돌연변이를 유발하지 않았다. 이것은 $\mathrm{CD}$ 유도체 가 인간의 피부에서 새로운 노화 방지제로서 안전하다는 것을 나 타낸다.

\section{3) $\mathrm{MBCD}$ 포접체의 항균 효과}

Isoliquiritigenin은 감초의 구성 성분으로서 항산화, 항균 활성과 같은 다양한 약리학적 활성을 가지고 있는 소수성 물 질이다. 소수성 약물의 용해도를 증진시키기 위해서 isoliq -uiritigenin/2-HDCD 복합체를 동결건조(freeze drying) 방식 으로 제조한 결과 용해도가 증가했을 뿐 아니라, 황색포도상구균 (Staphylococcus aureus)와 대장균(Escherichia coli)에 대하여 isoliquiritigenin/2-HDCD 복합체가 더 높은 항균 활성을 나타 내었다. 이는 isoliquiritigenin /2-HDCD 복합체가 식품 및 화장 품 산업에서 합성 방부제를 대체하고 천연 방부제로서 응용 가능

Table 1. Cosmetic stability effect of cyclodextrin host-guest inclusion complex

\begin{tabular}{|c|c|c|}
\hline Gest & Effect & Reference \\
\hline Esculin & $\begin{array}{l}\text { Improved solubility } \\
\text { Improved stability }\end{array}$ & Choi \& Ha, 2016 \\
\hline Hydrogel & $\begin{array}{l}\text { Improvement Hydrophobic drug complex } \\
\text { Release of drug }\end{array}$ & Lee et al., 2012 \\
\hline Coenzyme Q10 & $\begin{array}{l}\text { Improved thermal stability } \\
\text { Improved solubility }\end{array}$ & Lee et al., 2014 \\
\hline Genistein & $\begin{array}{l}\text { Improved stability and skin permeability } \\
\text { Anti-inflammatory } \\
\text { Strengthen skin barrier }\end{array}$ & Choi et al., 2018 \\
\hline
\end{tabular}


Table 2. Effect of $\beta$-cyclodextrin derivatives functional cosmetics

\begin{tabular}{|c|c|c|}
\hline Form & Effect & Reference \\
\hline methyl- $\beta$-cyclodextrin & $\begin{array}{l}\text { Caveolin-1 repression } \\
\text { collagen I expression increased. } \\
\text { None toxicity and side effect }\end{array}$ & Lee et al., 2015 \\
\hline $\begin{array}{l}\text { Isoliguiritigenin/ } \\
\text { methyl- } \beta \text {-cyclodextrin }\end{array}$ & Antimicrobial effect & Kim et al., 2015 \\
\hline \multirow{3}{*}{ Baicalein/cys- $\beta$-cyclodextrin } & Antioxidant activity improvement & Kim et al., 2016 \\
\hline & $\begin{array}{l}\text { Collagen I, } \Pi \text {, and } \mathbb{I} \text { expression increased. } \\
\text { Matrix metalloproteinase-1, }-3 \text { expression } \\
\text { decreased. }\end{array}$ & \multirow[t]{2}{*}{ Lee et al., 2019} \\
\hline & None pathologic collagen deposition & \\
\hline
\end{tabular}

성이 있음을 시사하고 있다(Kim et al,. 2015).

\section{4) $\beta-C D$ 유도체를 이용한 포접체의 항산화 효과}

Baicalein은 약용식물인 황금(Scutellaria baicalensis, 黃芩)의 뿌리에서 분리된 플라보노이드(flavonoid) 유형으로(Kim et al,. 2013) 항바이러스, 항종양, 항염증 작용으로 인해 주목 받고 있으 나, 용해도가 제한되어 flavonoid의 임상적 적용을 저해하였다.

Kim et al. (2016)의 연구에서는 baicalein의 수용해도와 항산 화 활성을 개선하기 위한 노력으로 Host-Guest 복합체를 준비 하고, Host 분자로 시스테인 기능기를 첨가하였다. 주사형 전자 현미경(Scanning Electron Microscope)분석을 통해 baicalein과 cysteinyl $\beta-\mathrm{CD}(\mathrm{Cys}-\beta-\mathrm{CD})$ 사이에 포접 복합체 형성과정이 일 어난 것을 관찰하였다. 물과 강한 친화력이 있는 시스테인 부위가 영향을 줌으로써 복합체의 baicalein이 물에 더욱 잘 용해되도록 도와주는 것으로 나타나 시너지 작용을 할 것을 기대하였다. 그 결과 시스테인을 결합시킨 후 $\beta-\mathrm{CD}$ 의 수용해도가 증가하여 $\mathrm{Cys}$ $\beta-\mathrm{CD}$ 복합체의 baicalein의 용해도와 항산화 능력을 향상시키는 효과가 관찰되었다.

Lee et al. (2019)의 연구에서는 Cys- $\beta-C D$ 과 Baicalein을 포 함하는 복합체(Cys- $\beta-\mathrm{CD}-$ baicalein)를 사용하여 이 물질의 피 부세포에 대한 효과를 제시하였다. 자외선을 조사한 후 $\mathrm{Cys}-$ $\beta-\mathrm{CD}$-baicalein 포접복합체가 Hs68 cells (인간 섬유아세포)의 콜라겐 합성에 미치는 영향과 그 효과의 근간을 이루는 메커니즘 을 조사했다. 그 결과 $\mathrm{Cys}-\beta-\mathrm{CD}$-baicalein 포접복합체는 콜라 겐 단백질인 $\mathrm{COL} \mathrm{I,} \mathrm{II,} \mathrm{III의} \mathrm{발현을} \mathrm{유의하게} \mathrm{증가시켰고,} \mathrm{콜}$ 라겐 분해 단백질인 $\mathrm{MMP}-1, \mathrm{MMP}-3$ 의 발현을 감소시켰다. 또 한 Caveolin-1의 발현감소와 tansforming growth factor-B (TGF-B) 신호전달 경로를 유도함으로써 콜라겐 회복을 유의하게 향상시켰다. 이러한 결과는 새로 합성된 $\mathrm{CD}$ 의 유도체가 baicalein 과 같은 플라보노이드의 생체이용률을 향상시키기 위한 복합체 형 성에 이용되었을 때 콜라겐 합성 복원에 기여할 수 있음을 시사하 였다. 또한 $\alpha$-smooth muscle actin ( $\alpha$-SMA) 발현에 대한 연
구결과로 치유과정에서 병리학적 콜라겐 침착과 흥터 형성의 지 표인 $\alpha-\mathrm{SMA}$ 발현을 유도하지 않음을 증명하였다. 따라서 $\mathrm{Cys}-$ $\beta-\mathrm{CD}$-baicalein 포접복합체가 흥터를 형성하는 부작용을 유발 하지 않으면서 콜라겐 합성을 유도하는 데 효과적인 것을 알 수 있었다. 따라서 Cys- $\beta-\mathrm{CD}$-baicalein 포접복합체는 피부 노화를 예방하고 치료하는 역할을 할 것으로 기대한다. $\beta-\mathrm{CD}$ 유도체를 이용한 포접체의 효과는 Table 2 와 같다.

\section{Conclusion}

$\mathrm{CD}$ 는 구조적으로 안정성이 높고 세포 독성이 없는 비교적 안전 한 물질로서 수용성을 증가시키는데 있어서 강점을 가지고 있다. $\mathrm{CD}$ 분자 내 소수성 공동에 불안정한 구조를 갖고 있는 각종 소수 성 화합물을 Guest물질로 사용하여 포접 복합체를 형성할 수 있 다. $\mathrm{CD}$ 포접 복합체는 외부적인 요인으로부터 보호받을 수 있을 뿐 아니라 산소, 열, 빛에 대한 안정성이 강화되고 수용해도를 증 가시킬 수 있다.

본 연구에서는 $\mathrm{CD}$ 포접과 관련한 선행논문을 고찰한 결과 esculin, hydrogel, coenzyme Q10, genistein과 같은 Guest 물 질의 포접에 성공하여 물질의 용해도를 향상시킴으로써 안정성효 과를 준다는 점을 확인하였다. 또한 $\mathrm{MBCD}$ 는 그 자체로서 세포노 화를 촉진하는 핵심분자인 caveolin-1을 억제함으로써 새로운 노 화방지제로서 사용될 수 있다는 가능성을 확인하였다. 다른 연구 에서는 flavonoid인 baicalein과의 포접체를 이용하여 항산화 활 성과 항균작용 및 콜라겐 증진효과를 보았다. 피부 상처 치유과정 에서 병리학적 콜라겐 침착과 흥터의 형성지표인 $\alpha-\mathrm{SMA}$ 의 발현 이 나타나지 않아 더욱 의미가 있었다. Isoliguiritigenin/CD 복합 체로 높은 항균 활성을 확인하여 합성 방부제를 대체할 천연 방부 제로서의 응용가능성을 시사하고 있다.

이렇게 천연물질의 효과를 증명하는 여러 연구들이 계속되고 있으나, $\beta-\mathrm{CD}$ 포접기능을 이용한 기능성 화장품을 개발하여 직 
접 사용감과 효과를 입증하는 임상 연구는 아직 부족하다. 앞으로 $\mathrm{CD}$ 의 구조적 특성을 활용한 연구를 통해 화장품 산업에서 유효성 분의 안정화 기술로서 상용화될 것을 기대한다.

\section{Author's contribution}

SP designed, conceptualized and supervised the review. JL collected literatures. SP and JL wrote the manuscript.

\section{Author details}

Jaeeun Lee (Graduate student), Department of Health and Cosmetics, Dongduk Women's University, 60 Hwarangro, 13-gil, Seongbuk-gu, Seoul 02748, Korea; Seyeon Park(Professor), Department of Applied Chemistry, Dongduk Women's University, 60 Hwarang-ro, 13-gil, Seongbuk-gu, Seoul 02748, Korea.

\section{References}

Barne S. The biochemistry, chemistry and physiology of the isoflavones in soybeans and their food products. Lymphatic Research and Biology, 8: 89-98, 2010.

Challa R, Ahuja A, Ali J, Khar RK. Cyclodextrins in drug delivery: an updated review. AAPS PharmSciTech, 6: 329-357, 2005.

Cho WG. Transdermal delivery system of effective ingredients for cosmeceuticals. Journal of the Society of Cosmetic Scientists of Korea, 37: 97-119, 2011.

Choi YK, Ha BJ. Preparation and physicochemical properties of the host-guest inclusion complex of esculin with hydroxypropyl- $\beta$-cyclodextrin. Journal of Investigative Cosmetology, 12: 205-211, 2016.

Choi DJ, Cho UM, Choi DH, Hwang HS. Effects of antiinflammation and skin barrier by genistein cyclodextrin complex. Journal of the Society of Cosmetic Scientists of Korea, 44: 171-181, 2018.

Drummond DC, Meyer O, Hong K, Kirpotin DB, Papahadjopoulos D. Optimizing liposomes for delivery of chemotherapeutic agents to solid tumors. Pharmacological Reviews, 51: 691743, 1999.

Del Valle EMM. Cyclodextrins and their uses: a review. Process Biochemistry, 39: 1033-1046, 2004.

Jang SK, An SK, Jeon SH. The moisturizing effect and formulation test of the cosmetics composed by horse oil liposomes. Asian Journal of Beauty and Cosmetology, 12: 813-820, 2014.

Kaneko T, Tahara S, Takabayashi F. Inhibitory effect of natural coumarin compounds, esculin and esculin, on oxidative DNA damage and formation of aberrant crypt foci and tumors induced by 1,2-dimethyl hydrazine in rat colons. Biological and Pharmaceutical Bulletin, 30: 2052-2057, 2007.

Kim HS, Im NR, Park SN. Enhanced antimicrobial activities and physicochemical characteristics of isoliquiritigenin encapsulated in hydroxypropyl- $\beta$-cyclodextrin. Applied Chemistry for Engineering, 26: 719-724, 2015.

Kim H, Yiluo H, Park S, Lee JY, Cho E, Jung S. Characterization and enhanced antioxidant activity of the cysteinyl $\beta$-cyclodextrin-baicalein inclusion complex. Molecules, 21: E703, 2016.

Kim NY, Mun JS, Choi TB. Effect of Scutellaria baicalensis extract metalloproteinase-1 on the expression of UV-Birradidated human dermal fibroblast. Asian Journal of Beauty and Cosmetology, 11: 649-654, 2013.

Kyong KY. R\&D trends of functional cosmetics. KIC News, 13: 1-10, 2010.

Kfoury M, Landy D, Auezova L, Greige-gerges H, Fourmentin S. Effect of cyclodextrin complexation on phenylpropanoids's solubiloty and antioxidant activity. BEILSTEIN Journal of Organic Chemistry, 10: 23222331, 2014.

Lee MS, Hong SK, Kim JC. Cyclodextrin-based hydrogels and their applications. Polymer Science and Technology, 23: 13-20, 2012.

Lee JK, Lee HJ, Lim JK. Structural and solubility characteristics of coenzyme Q10 complexes including cyclodextrin and starch. Korean Journal of Food Science and Technology, 46: 180-188, 2014.

Lee JM, Ahn ES, Kim SY, Shin YJ, Sung JH, Kim HH, Cho EA, Jung SH, Park SY. Inclusion complexes of cysteinyl $\beta$-cyclodextrin with baicalein restore collagen synthesis in fibroblast cells following ultraviolet exposure. Journal of Cellular Biochemistry, 120: 4032-4043, 2019.

Lee JA, Choi DI, Choi JY, Kim SO, Cho KA, Lee JB, Yun SJ, Lee SC. Methyl- $\beta$-cyclodextrin up-regulates collagen I expression in chronologically-aged skin via its anti- 
caveolin-1 activity. Oncotarget, 6: 1942-1995, 2015.

Müller-Goymann CC. Physicochemical characterization of colloidal drug delivery systems such as reverse micelles, vesicles, liquid crystals and nanoparticles for topical administration. European Journal of Pharmaceutics and Biopharmaceutics, 58: 343-356, 2004.

Tang J, Xu N, Ji H, Liu H, Wang Z, Wu L. Eudragit nanoparticles containing genistein: formulation, development, and bioavailability assessment. International Journal of Nanomedicine, 6: 2429-2435, 2011.

Singh M, Sharma R, Banerjee UC. Biotechnological applications of cyclodextrins. Biotechnology Advances, 20: 341-359, 2002.

Song SC, Jo JG, Jeon CJ. Drug delivery technology using hydrogel. News \& Information for Chemical Engineers, 28: 171-177, 2010.

Volonte D, Zhang K, Lisanti MP, Galbiati F. Expression of caveolin-1 induces premature cellular senescence in primary cultures of murine fibroblasts. Molecular Biology of the Cell, 13: 2502-2517, 2002. 


\section{국문초록}

\section{사이클로덱스트린(Cyclodextrin)의 화장품 유효성분으로서의 유용성 고찰}

이재은 ${ }^{1}$, 박세연 ${ }^{2 *}$

${ }^{1}$ 동덕여자대학교 보건향장학과, 서울, 한국

${ }^{2}$ 동덕여자대학교 응용화학과, 서울, 한국

피부는 신체의 가장 바깥에 위치하며 외부환경의 영향은 피부노화의 원인이 되기도 한다. 화장품을 이용한 피부의 노화 지연을 위 한 노력에 있어서 화장품 성분의 안정화 기술 방법은 그 기능을 극대화 시키는데 있어서 중요하다. 마이크로캡슐화, 리포좀, 액정공 법 이외에도 사이클로덱스트린(cyclodextrin)의 구조적 특성을 이용하여 물질의 용해성 및 안정성 증진, 서방형(徐放型)성질을 향상 시켜 생체 이용률을 증가시키는 연구가 다양하게 진행되고 있다. 이에 본 총설에서는 cyclodextrin의 구조적 특성을 이용하여 다양 한 유효성분의 화장품 원료로서의 유용성을 높일 수 있는 선행연구들을 고찰하였다. Esculin, hydrogel, coenzyme Q10, genistein 의 cyclodextrin 포접체와 포접하지 않은 상태의 각각의 물질과 비교한 결과 용해도가 증가하였고, 생물학적 안정성 및 피부투과율 이 개선되었다. 또한, $\beta$-Cyclodextrin에 아미노산인 시스테인구조 단위를 결합시켜서 만든 cysteinyl $\beta$-cyclodextrin은 플라보노 이드인 baicalein에 특이적인 포접 기능을 보여서 복합체를 만들었다. 물과 강한 친화력이 있는 시스테인 부위가 영향을 줌으로써 복합체는 baicalein이 물에 더욱 잘 용해되도록 도와주는 것으로 나타났다. 따라서 cysteinyl 그룹을 첨가한 구조 이외에도 다양한 cyclodextrin 구조의 유도체를 합성하여 Host 구조의 종류를 증가시킴으로써 이미 검증된 유효성분들의 효능을 부가시킬 수 있는 구조 특이적인 Host를 제시하는 연구도 의미가 있을 것으로 생각된다. 또한 추후에 $\beta$-cyclodextrin의 포접기능을 이용한 기능성 화 장품으로서의 효과를 입증하는 임상 연구 등이 보강된다면, cyclodextrin은 화장품 산업에서 유효성분의 안정화 소재로서 상용화될 것으로 기대할 수 있다.

핵심어: 화장품 유효성분, 화장품 성분 안정화 기술, 사이클로덱스트린 포접체, 용해도, 안정성

\section{참고문헌}

김나영, 문지선, 최태부. 자외선을 조사한 인간 섬유아세포에서 황금추출물과 황금주요플라보노이드 성분이 $\mathrm{MMP}-1$ 발현 에 미치는 영향. 아시안뷰티화장품학술지, 11: 649-654, 2013.

김해수, 임나리, 박수남. 아이소리퀴리티게닌을 담지한 2-하이드록시프로필-베타사이클로덱스트린의 물리화학적 특성 및 항균활성 연구. 공업화학, 26: 719-724, 2015.

이미선, 홍성경, 김진철. 사이클로덱스트린 하이드로겔의 최신 연구 동향 및 응용. 고분자 과학과 기술, $23: 13-20$, 2012.

이준경, 이현주, 임재각. 사이클로덱스트린과 전분을 이용한 coenzyme Q10 복합체의 특성 연구. 한국식품과학회지, 46 : 180-188, 2014.

조완구. 기능성화장품을 위한 유효성분의 경피 전달 시스템. 대한화장품학회지, 37: 97-119, 2011.

장상규, 안성관, 전소현. 마유 리포좀제조 및 마유 리포좀이 포함된 화장품의 제형 및 보습효과 연구. 아시안뷰티화장품학 술지, 12: 813-820, 2014.

최동준, 조욱민, 최다희, 황형서. 제니스테인 Cyclodextrin 포접체의 함염 및 피부장벽에 미치는 영향. 대한화장품학회지, 44: 171-171, 2018.

최윤경, 하병조. 하이드록시프로필-베타-사이클로덱스트린과 에스큘린의 호스트-게스트 포접 착화합물의 제조와 물리화 학적 성질. 대한미용학회지, 12: 205-211, 2016. 


\section{中文摘要}

\section{环糊精 (Cyclodextrin ) 作为有效化妆品成分的用途}

李在殷 ${ }^{1}$, 朴世蓮 $^{2 *}$

1同德女子大学保健香妆学科，首尔，韩国

2 同德女子大学应用化学科, 首尔, 韩国

皮肤位于身体的最外侧，外部环境的影响会导致皮肤老化。在使用化妆品延缓皮肤衰老的努力中，化妆品成 分的稳定化技术对于最大化其功能很重要。除了微囊化, 脂质体和液晶方法, 还进行了各种研究, 以通过改 善材料的溶解性和稳定性来增加生物利用度, 并通过利用环糊精的结构性质来改善徐放型性能。在这篇综述 中, 我们回顾了以前的研究，以通过使用环糊精的结构性质来提高各种活性成分作为化妆品成分的实用性。将 Esculin，水凝胶，辅酶Q10和染料木黄酮的环糊精包合物与每种非包合物材料进行了比较。结果表明，环糊精 增加溶解度并改善皮肤渗透性。另外，通过将氨基酸半胱氨酸结构单元与 $\beta$-环糊精结合而制成的半胱氨酸 $\beta$-环 糊精显示出对黄酮类baicalein特有的复合功能。通过影响与水有很强亲和力的半胱氨酸部位, 该复合物已被 证明可以帮助baicalein更好地溶于水。因此，除了半胱氨酰基団的结构外，一项研究提出了一种结构特异性 宿主，该宿主可以通过合成各种环糊精结构衍生物来增加宿主结构的类型，从而增加已经证实的有效成分的功 效，这被认为是有意义的。另外，如果将来进行临床研究以利用 $\beta$-环糊精的包合功能证明作为功能性化妆品的 效果的临床研究，则可以期望将环糊精商品化为化妆品工业中的活性成分的稳定材料。

关键词: 化妆品有效成分，化妆品成分稳定技术，环糊精包合物，溶解性，稳定性 
